\title{
Population structure and reproductive patterns of the NW Mediterranean deep- sea macrourid Trachyrincus scabrus (Rafinesque, 1810)
}

U. Fernandez-Arcaya $\cdot$ L. Recasens · H. Murua · E. Ramirez-Llodra · G. Rotllant · J.B. Company

Institut de Ciències del Mar (ICM-CSIC), Passeig Marítim de la Barceloneta 3649, 08003 Barcelona, Spain

Azti Tecnalia, Herrera Kaia-Portualdea z/g - 20110 Pasaia, Gipuzkoa, Spain IRTA, Poble Nou, Km 5,5 43540 Sant Carles de la Ràpita, Tarragona, Spain

\footnotetext{
* Corresponding author. Tel :+34 932309 500; Fax +34 392309555

E-mail address: ulla@icm.csic.es (U. Fernandez-Arcaya)
}

\begin{abstract}
Macrourid fish are one of the most abundant marine species on continental margins worldwide. Although they play an important role in the ecosystem, little is known about their overall biology. We report here a large dataset of the most abundant macrourid in Mediterranean waters, Trachyrincus scabrus, showing the main population and reproductive characteristics. The study was based on 3239 specimens collected between 300 and $1500 \mathrm{~m}$ depth on the northwestern Mediterranean in 2003-04 and 2008-09. The population showed a depth-related structure with the largest individuals at $1100 \mathrm{~m}$ depth and the smallest (i.e., immature) at shallower depths. Macroscopic and microscopic analyses of the gonads showed that $T$. scabrus has a highly seasonal reproductive pattern. Spawning females were found during winter when the organic matter fluxes were highest on the continental slope. T. scabrus is a batch spawner with group-synchronous oocyte development and present low average fecundity of 14191 oocytes.
\end{abstract}

Keywords:

Trachyrincus scabrus, population structure, reproductive biology, deep-sea, NW Mediterranean 


\section{Introduction}

Macrourids are one of the most abundant fish families found on continental slopes worldwide (Marshall 1965; Bergstad 1990), playing an important role in the bathyal food web (Merrett and Haedrich 1997). Most research has concentrated on a few species because of the commercial interest of certain species, such as Macrourus berglax (Haedrich and Merrett 1988; Murua and Motos 2000) and Coryphaenoides rupestris (Bergstad 1990; Gordon and Swan 1996; Kelly et al. 1996). The overall ecology of the family, however, is still largely unknown despite its relevance in terms of biomass. There are eight macrourid species in the Mediterranean Sea (Moranta et al 2007), which inhabit depths between $200 \mathrm{~m}$ and $3000 \mathrm{~m}$. Some aspects of the distribution, size range, reproduction and feeding habitats of these species have already been studied (D'Onghia et al. 1999; Carrasson and Matallanas 2002; Moranta et al. 2008). Trachyrincus scabrus occurs at depths between 300 and $1600 \mathrm{~m}$ in the Mediterranean Sea (Stefanescu et al. 1992) and is one of the most important continental slope species in terms of abundance and biomass (Stefanescu et al. 1993; Tecchio et al. 2011). This species constitutes an important fraction of the total discards generated by deep-sea bottom trawling in the northwestern Mediterranean (Sánchez et al. 2007). Like other macrourids, Trachyrincus scabrus feeds on epibentic and infaunal invertebrates down to $800 \mathrm{~m}$ depth (Macpherson 1979), while below $1000 \mathrm{~m}$ depth, individuals exhibit a preference for benthopelagic prey (Carrasson and Matallanas 2002).

The water masses of the Mediterranean are considered oligotrophic and are characterized by a constant high temperature $\left(\sim 13^{\circ} \mathrm{C}\right)$ below $200 \mathrm{~m}$ depth, high salinity, low light and no oxygen limitation (Hopkins 1985; Sardà et al. 2004). These physicochemical factors are thought to condition the success of adaptive processes of species that inhabit deep-sea environments, leading to slow growth, low metabolic rates and low fecundity (Gage and Tyler 1991; Childress 1995; Tyler and Sumpter 1996; Merrett and Haedrich 1997; Company and Sardà 1998; Ramirez-LLodra 2002; Company et al. 2003; Priede et al. 2003). These biological characteristics translate into less plasticity and higher vulnerability to environmental change and fishing pressure (Koslow et al. 2000; Herring 2002; Roberts 2002). In this context, T. scabrus highlights the increasingly significant impact that fishing has on deep-sea fish populations. A clear decrease in body size of this species at higher latitudes has been observed in the Mediterranean Sea as a result of the intensive trawling carried out by the fishery targeting the deep-sea red shrimp Aristeus antennatus in part of the bathymetric range of T. scabrus (Moranta et al. 2007). In contrast, in the Alboran Sea basin, where the 
open slope remains unexploited below $500 \mathrm{~m}$ depth, T. scabrus has a broader length range in which larger individuals predominate (Moranta et al. 2007).

There is little information on seasonality phenomena in deep-water fish species due to the difficulty of repeating sampling consistently at such great depths and the high economical cost involved. However, it is very important to determine the seasonality and duration of the reproductive processes of a species in order to understand its population dynamics and evolutionary adaptation to the environment (Marshall and Browman 2007; Lowerre-Barbieri et al. 2011). Although T. scabrus is important both in terms of abundance and biomass, its reproductive characteristics are still mostly unknown. Motais (1960) analyzed the variation of the annual gonadosomatic index of $T$. scabrus in the Ligurian Sea, showing high values in February. Additionally, two more studies included data on reproduction; D'Onguia et al. (1996) for the Ionian Sea and Massutí et al. (1995) for the western Mediterranean Sea. However, the reproductive period of this species was not clearly defined in either of these two studies because of the small number of mature individuals captured. No data related to reproductive strategy and fecundity were available prior to our study.

The main objective of this study was to define the seasonal trends in population structure and reproductive biology of $T$. scabrus in the northwestern Mediterranean Sea. The research is based on the analysis of the bathymetric size distribution, spawning period, ovarian organization, fecundity type and fecundity values. These data can be used to develop appropriate management measures to ensure the sustainability of this species as a potential deep-sea fishery resource in the Mediterranean Sea.

\section{Materials and methods}

Study area and sampling strategy

The samples were collected in 87 bottom trawls carried out in the Blanes canyon $\left(41^{\circ} 34^{\prime} \mathrm{N}, 02^{\circ} 50^{\prime} \mathrm{E}\right)$ and on the adjacent open slope $\left(41^{\circ} 15^{\prime} \mathrm{N}, 02^{\circ} 48^{\prime} \mathrm{E}\right)$ as part of two

multidisciplinary nationally funded projects, RECSII and PROMETEO (Fig. 1). During the RECS project, samples were obtained every month and a half on board the R/V García del Cid and the F/N Montse III and Verge del Vilar. Sampling was conducted from April 2003 to May 2004 at depths between 300 and 900 m (Table 1) where maxima abundance of immature individuals were present. To sample the reproductive individuals, seasonal sampling was conducted on board the R/V García del Cid from November 2008 to November 2009 at depth intervals of 150 m between 900 and 1500 
$m$ depth (PROMETEO project) (Table 1). The bathymetric range covered was 300 to $1500 \mathrm{~m}$, and thus the entire depth range interval of this species was sampled. Samples were obtained using a commercial fishing net covered with a cod-end of $12 \mathrm{~mm}$ stretch mesh on board fishing vessels and with a modified commercial fishing net - Otter Trawl Maireta System (OTMS, Sardà et al., 1998) - with the same cod-end mesh size on board the research vessel.

All individuals were measured to the nearest $0.5 \mathrm{~cm}$ anal length $(A L)$ and weighed to the nearest gram using a marine scale (P15 S-182/5). Sex was determined by macroscopic examination of the gonad. The individuals collected during the PROMETEO project were used for studying the reproductive biology. The gonads were macroscopically classified into a five-stage maturity scale according to their external appearance and using the standardized terminology in Brown-Peterson et al. (2011): I: immature; II: developing-regenerating, III: spawning capable, IV: active spawning, and $\mathrm{V}$ : regressing. Gonads were then dissected and preserved in $10 \%$ buffered formaldehyde for histological analyses.

Data analyses

All the data were normalized to an area of $1 \mathrm{~km}^{2}$ using the vessel trawling speed and average horizontal opening of the gear. On trawls above $1200 \mathrm{~m}$ depth, the SCANMAR system was used to determinate the arrival and departure of the net from the bottom, as well as the horizontal and vertical opening of the net. For the deepest samples (i.e., 1350 and $1500 \mathrm{~m}$ ), net opening was obtained from the average of all other trawls conducted during the same cruise.

Size-frequency distributions of individuals were plotted in relation to depth and season. After standardization of samples from each trawl to a $1 \mathrm{~km} 2$, data was pooled by the bathymetric ranges used in this study (i.e., every 150 to $175 \mathrm{~m}$ ) and by season. All data were tested for normality using the Shapiro-Wilk's test. For data that did not satisfy the assumptions of normality, even after transformation, non-parametric Kolmogorov-Smirnov tests were used to determine differences in size distribution by depth. Differences in size between males and females were determined using a MannWhitney $U$ test and the sex ratio by depth was analyzed with a Yates corrected chisquare test. In the laboratory, all the gonads were weighed to the nearest $0.001 \mathrm{~g}$. The gonadosomatic index (GSI) was calculated as the ratio between gonad weight $(\mathrm{Wg})$ and the gonad-free weight of the individual, where Tw was the total individual weight: $\mathrm{GSI}=(\mathrm{Wg}) /(\mathrm{Tw}-\mathrm{Wg}) \times 100$. Seasonal variations in gonad maturity were investigated pooling all the mature females from PROMETEO project. 
The length at first maturity was defined as the anal length at which $50 \%$ of the females were mature, considering all females in the developing stage (stage II), and onwards, to be mature. The relationship between maturity and length was fitted to a logistic equation (Ashton 1972): $P=e^{\wedge}(\alpha+\beta L) /\left(1+e^{\wedge}(\alpha+\beta L)\right.$, where $P$ is the predicted mature proportion, $\alpha$ and $\beta$ are the coefficients of the logistic equation and $L$ is the anal length in $\mathrm{cm}$.

Histological analysis

In order to confirm the macroscopic determination of maturity stage, a subsample of gonads was analyzed histologically. Samples $(n=200)$ were embedded in paraffin blocks and sectioned at $7 \mu \mathrm{m}$. These sections were stained with Harris' Haematoxylin and Eosin. In addition, to obtain a more comprehensive understanding of the gonad anatomy, 50 ovaries were embedded in resin, cut at $3 \mu \mathrm{m}$ intervals and stained with periodic acid Schiff's hematoxylin metanil yellow (Quintero-Hunter et al. 1991). We applied the criteria in Brown-Peterson et al. (2011) with some modifications to classify the ovarian maturity stage. Primary vitellogenic oocytes and secondary vitellogenic oocytes were described as early vitellogenic oocytes, and tertiary vitellogenic oocytes were classified as advanced vitellogenic oocytes. The diameters of 100 oocytes from each developmental stage were measured with Sigma Scan Pro4 and the size range of the different oocyte developmental stages was calculated.

Oocyte analysis and fecundity

A total of 53 gonads, covering all ovary developmental phases, were selected for analyzing the oocyte-size frequency distribution. A small subsample of approximately $0.07 \mathrm{~g}$ from each gonad was stained with Rose Bengal and then filtered through a 125$\mu \mathrm{m}$ sieve. Oocytes smaller than this size were not considered in the analysis. The filtered subsamples were photographed using a Canon camera attached to a binocular (Leyca MZ12) microscope. These photographs were analyzed by ImageJ image analysis software (Thorsen and Kjesbu 2001).

Total fecundity was defined as the total number of advanced vitellogenic oocytes present in the ovary at any time (Hunter et al. 1992). Twenty five individuals in the spawning capable (III) and actively spawning (stage IV) phases were selected to estimate fecundity with the gravimetric method. A subsample of the whole ovary was weighed to the nearest $0.001 \mathrm{~g}$ and the number of mature oocytes was counted using image analysis software ImageJ (Thorsen and Kjesbu 2001). Batch fecundity was 
estimated by counting the hydrated oocytes manually (Hunter et al. 1985). Total (F) and batch $(\mathrm{BF})$ fecundity were calculated as: $\mathrm{F}=[\mathrm{Oi} / \mathrm{Wi}] \times \mathrm{Wo} ; \mathrm{BF}=[\mathrm{Oh} / \mathrm{Wi}] \times \mathrm{Wo}$, where Oi is the number of oocytes in the advanced vitellogenic stage and all the following stages, Oh is the number of hydrated oocytes, Wi is the weight of the ovary subsample, and Wo is the ovary weight. In addition, relative total fecundity and batch fecundity were estimated by dividing the two parameters by the gonad-free weight of the fish.

\section{Results}

Distribution and size composition

A total of 3239 individuals were collected, ranging between 2 and $20 \mathrm{~cm}$ anal length $(A L)$. The population had a "V-shape" structure in relation to increasing depth (Fig. 2). The largest fish were found at intermediate depths of the distribution range between 900 and $1050 \mathrm{~m}$. An increase in individual size with depth was observed from 300 to $1050 \mathrm{~m}$ depth, while below this depth the individual size slightly decreases. The Kolmogorov-Smirnov test showed significant differences in the size-frequency distribution between all depths except in the individuals distributed between 900 and $1050 \mathrm{~m}$ and $1200 \mathrm{~m}$ and $1350 \mathrm{~m}$ depths (Table 2). In addition, adults and juveniles had different bathymetric distribution patterns (Fig. 2): the juveniles were concentrated between $300 \mathrm{~m}$ and $800 \mathrm{~m}$ depth, while adults were distributed mainly between $900 \mathrm{~m}$ and $1500 \mathrm{~m}$. Individuals where the sex could not be determinate by macroscopic examination of the gonads were considered as immature and, hence, juveniles. Females were significantly larger than males (Mann-Whitney U-test, $U=436433$, $\left.N_{1}=915, N_{2}=1076, P=<0.0001\right)$. No significant differences in sex ratio were observed at any depths (Yate corrected chi-square, $p>0.05$ ). Males predominate in individuals between 10 and $16 \mathrm{~cm}$, whereas females were predominant in the larger size classes $(>16 \mathrm{~cm})$ (Fig. 3). The sex proportions for each depth are shown in percentages in Table 3. The overall sex ratio was 1:0.85 for females vs males.

Reproductive patterns and size at first maturity

Six different ovary stages of Trachyrincus scabrus were described based on the maturity scale defined by Brown-Peterson et al. (2011). The characteristics of each gonad developmental stage for this species are shown in Table 4 and Fig. 4. Early stage II and stage VI could not be differentiated at the naked eye and so histological 
sections were needed to classify the reproductive maturity stage of these gonads. However, because not all the samples were classified microscopically and because misclassifications could have occurred in the macroscopic staging, stages II and VI were merged to analyze the seasonality of the spawning stage. The seasonal evaluation of female maturity stages showed that $T$. scabrus females have a highly seasonal reproductive cycle. Mature females (III-IV) are present from autumn to winter (Fig. 5). During autumn, most of the females started the vitellogenic process and there was a high percentage of females in the developing and spawning capable stages. The actively spawning females (IV) were observed mainly in winter and constituted up to $43 \%$ of the population. Developing-regenerating (II-VI) females occurred mainly in spring and summer. In all seasons, except winter, individuals with stage II-VI gonads represented more than $50 \%$ of the sampled population. The highest gonadosomatic index (GSI) values were observed in winter (Fig. 6), coinciding with the spawning period. The bathymetric distribution of the different female developmental stages during the reproductive period (winter) showed that the highest percentage of active spawning females was found at $1050 \mathrm{~m}$ depth. However, females showing gonads with the other developmental stages were most abundant at $900 \mathrm{~m}$ depth, where the highest number of individuals was found (Table 5). On the other hand, the individual size distributions by season are in agreement with the reproductive characteristics of the species. Early recruitment individuals were observed in spring, 2-3 months after the end of the spawning period (winter). During the next autumn, this cohort was sampled and the individual size of recruits was in the range of $4-7 \mathrm{~cm} \mathrm{AL}$ (Fig. 7). The size of first maturity was estimated as follows: the proportion of mature females (stages II, III, IV and V) (Fig. 8) was fitted to a logistic curve. The estimated mean anal length (L50) at which $50 \%$ of females was mature was $11.8 \mathrm{~cm}$.

The oocyte size-frequency distribution is shown in Fig. 9. Females with gonads in stage II had a single cohort of oocytes with diameters from 125 to $275 \mu \mathrm{m}$ (Fig. 9a), including oocytes in primary growth, cortical alveoli and early vitellogenic oocyte stages. Females with gonads in stage III (Fig. 9b) had a single cohort of larger oocytes (375-675 $\mu \mathrm{m})$ composed of advanced vitellogenic oocytes and gerrminal vesicle migration oocytes, when present. In contrast, gonads in stage IV (Fig. 9c) showed a bimodal distribution: smaller oocytes (500-675 $\mu \mathrm{m})$ were composed of advanced vitellogenic oocytes, and larger oocytes $(775-925 \mu \mathrm{m})$ were in the germinal vesicle migration or hydration stages, and so would be the next batch to be spawned. There was therefore synchronous oocyte development within the ovary.

Fecundity 
The fecundity of 25 individuals were calculated by counting all oocytes with diameters larger than $337 \mu \mathrm{m}$ (average size of advance vitellogenic oocytes), which clearly marks the oocyte development threshold that determines the potential fecundity. Fecundity values ranged from 4187 to 43643 oocytes for females measuring between $13 \mathrm{~cm}$ and $18 \mathrm{~cm}$. The fecundity values ranged from 4187 to 26111 oocytes in all the females except one female of $16 \mathrm{~cm}$ that had higher fecundity (43643 eggs). Batch fecundity was estimated to be in the range of 2582 to 9489 oocytes. Relative total fecundity and relative batch fecundity were estimated at 82.9 and 33.7 oocytes per gram of female (gonad free weight) respectively (Table 6 ). The results indicate that fecundity is not size dependent $\left(r^{2}=0.50, F_{1,23}=1.23, P=0.45\right)$ (Fig. 10a), as there was high individual variability in the fecundity-size relationship. In contrast, there was a significant positive correlation between gonad weight and total fecundity $\left(r^{2}=0.46, F_{1,23}=19.71, P<\right.$ 0.001 : including all individuals; $r^{2}=0.61, F_{1,22}=34.71, P<0.001$ : except for the abovementioned outlier) (Fig. 10b). No relationship was observed between batch fecundity and size $\left(r^{2}=0.02, F_{1,10}=0.18, P=0.68\right)$.

\section{Discussion}

A seasonally and bathymetrically extended trawl survey was carried out in order to collect a large number of specimens of the macrourid fish species Trachyrincus scabrus. The results of the study show that the reproductive and population characteristics are related to the depth range of this species. We present here, for the first time for this species, data on size at first sexual maturity, entire gonad maturity cycle, reproductive strategy and fecundity, and thus contribute to a better understanding of the biology and ecological role of this important species. The information on the biology of $T$. scabrus enhances our general understanding of the biological responses of the species that inhabits physico-chemically variable environments, such as the continental margins (Levin and Dayton 2007), and provides further insight into the effects of such variable environments on the population distribution and reproduction processes of these species.

The population structure showed a clear depth-related pattern in size distribution: the average individual size increased down to $1100 \mathrm{~m}$ depth. The increase of individual size by depth was described as a "bigger-deeper" phenomenon and has been observed in many deep-sea fish species. (Polloni et al 1979; Stefanescu et al 1992; Merret and Headrich 1997; Murua 2003; Sardà et al 2009). However, below 1100 
m depth, this species showed a slight "smaller-deeper" trend. There are two possible causes for the change in size trends around $1100 \mathrm{~m}$. First, fish might migrate ontogenetically from shallow to deep waters, as has been observed in other continental margin species (Macpherson and Duarte 1991; Massutí et al. 1995). Company et al. (2001) and Puig et al. (2001) suggest that the bathymetric size structure of several decapod crustacean species could be related to the presence of high concentrations of particulate matter within the nepheloid layers at around $400 \mathrm{~m}$ depth, which could generate a favorable area for the recruitment of these crustacean species. In the area where T. scabrus samples were taken, an intermediate bottom nepheloid layer was recorded at 400-600 m depth (Zúñiga et al. 2009). The fact that $T$. scabrus recruits are mainly concentrated at $400-600 \mathrm{~m}$ suggests that the frontal system could play an important role in the population structure of $T$. scabrus in our study area. The second possible explanation could be related to the fact that there is less food availability below 1100 m (Sardà and Cartes 1993; Stefanescu et al. 1993), resulting in the decrease in size down to $1500 \mathrm{~m}$ depth (maximum depth distribution of the species). In fact, T. scabrus changes its feeding habits below $1000 \mathrm{~m}$ depth (Carrasson and Matallanas 2002), which coincides with the change in the size distribution pattern. From 200 to $800 \mathrm{~m}$ depth, the diet of T. scabrus is rather stenophagous, feeding heavily on decapods that live buried on the mud (Macpherson 1979). However, below $1000 \mathrm{~m}$ depth, this species shows a benthopelagic diet with a slight preference for bathypelagic prey such as copepods and mysids (Carrasson and Matallanas 2002).

The concept of continuous biological processes linked to the theoretically constant deep-sea environment has been revised over the last decades, and both seasonal and continuous reproductive patterns have been found in continental slope fish species (Morales-Nin et al. 1996; Rotllant et al. 2002; Porcu et al. 2010). Tyler et al. (1982) and Gage and Tyler (1991) postulated that seasonal reproductive processes are a response to the natural fluctuations in environmental factors. In the study area, Zuñiga et al. (2009) showed that there is high seasonal variability in downward fluxes of larger particles, with higher values in autumn and winter. T. scabrus has a marked seasonal reproductive cycle, and spawning females are mainly present in the winter months, coinciding with the seasonal fluxes of organic matter from the photic zones. Massutí et al. (1995) found post-spawning females in the western Mediterranean in the spring months. Although these authors did not find spawning females, their data on the reproductive period of $T$. scabrus in the western Mediterranean are in agreement with our data. In contrast, a study conducted in the central Mediterranean Sea found spawning females in August and January (D'Onghia et al. 2000), which suggests that the breeding season differs depending on the region. This implies that environmental 
conditions could play an important role in determining the reproductive processes of this deep-sea species. Based on the assumption that reproductive cycles have adapted to fluxes of organic matter from the photic zone (Herring 2002; Company et al. 2003), autumn is the period in which energy reserves are accumulated to enhance fish condition for the reproductive phase. Accordingly, the highest gonadosomatic index values and spawning females were mainly observed in winter. However, the low levels of nutrients sinking down to the deep sea from the euphotic layers may not be enough for fish to invest in reproduction every year. A high percentage of non-spawning females (30\%) was found also during the spawning period. Massutí et al. (1995) did not find spawning females even though the sampling was conducted in the depth range at which reproductive females of $T$. scabrus are most abundant. Taking into account the data from the two studies, we suggest that not all individuals of this species breed every year. This phenomenon has been described in other deep-sea fish species, such as Hoplostethus atlanticus (Bell et al. 1992) and the macrourid Coryphaenoides acrolepis (Drazen 2002). Biannual spawning could be an adaptive response to the low food availability in deep-sea habitats, particularly in the oligotrophic Mediterranean Sea (Margalef 1986)

The highest percentage of active spawning females was found at $1050 \mathrm{~m} \mathrm{(46 \%}$ of total females), but the other female maturity stages (i.e., reproductive stages II, III, IV and $\mathrm{V}$ ) were mainly concentrated at $900 \mathrm{~m}$ depth, indicating that females may migrate to deeper areas (from 900 to $1050 \mathrm{~m}$ ) to spawn. However, our knowledge of the role played by environmental factors and of species interactions in the deep sea is still too limited to describe a spatio-temporal correlation between the environmental conditions and the biological response (Aguzzi et al. 2010).

The reproductive strategy of $T$. scabrus shows discontinuous oogenesis with synchronous development of vitellogenic oocytes. Image analysis shows that there is one cohort of oocytes in mature ovaries. Two groups of oocytes are only observed when final maturation of oocytes occurs: a group of large oocytes in the hydration phase and a group of smaller oocytes in the advanced vitellogenic and germinal vesicle migration stages that form the next batch to be spawned during the following spawning event. We believe that primary growth oocytes, due to their small diameter, could have escaped through the mesh $(<125 \mu \mathrm{m})$ used to process the samples for image analysis. This is corroborated by the histological characteristics of females in stage IV (Fig. 4d, e), in which primary growth oocytes were found. Therefore, this species could be considered a batch spawner with group-synchronous oocyte development, in which two distinct populations of oocytes appear at the same time: one forming the potential fecundity for the current spawning season and the other forming the oocyte population 
for future spawning seasons (Murua and Saborido-Rey 2003). This type of ovarian organization has also been found in other macrourid species, such as Coryphanoides rupestris (Alekseyev et al. 1991; Kelly et al. 1996) and Macrourus berglax (Murua and Motos 2000), and is related to species with a relatively short spawning period, in which the accumulation of yolk depends mainly on body reserves (Murua et al. 2003).

Deep-sea fish generally show low fecundity in comparison with shallower species (Gage and Tyler 1991; Merrett and Haedrich 1997; Herring 2002). T. scabrus has determinate fecundity and batch spawning (Tyler and Sumpter 1996) with values between 4187 and 43643 eggs. Two macrourid fish that are larger than T. scabrus, Coryphaenoides rupestris and Macrourus berglax, show fecundity ranges between 11083 and 55175 oocytes (Kelly et al. 1996) and between 14400 and 73220 oocytes (Murua and Motos 2000) respectively. In contrast, the absolute individual fecundity of smaller macrourid species, such as Coelorinchus coelorhincus and Nezumia sclerorhynchus, has been estimated between 1320 and 8897 and between 964 to 3553 oocytes per female respectively on the Mediterranean Sea (D'Onguia et al. 2008). Fecundity values are related to several factors, such as food supply (Treasure 1981), population density (Bagenal 1973), allocation of energy to reproduction (Kennedy et al. 2007) and fish size (Merrett 1994). In the present study, in contrast to the results obtained in other macrourids species (D'Onguia et al, 2008), no significant relationship between fish size and fecundity was observed. Similarly, Alekseyev et al. (1991) did not find a clear positive relationship between length and relative fecundity in Coryphaenoides rupestris, but rather they found relatively high variability in fecundity for the same size range. This could be because sampling was conducted during the spawning season and some of the fish sampled could have spawned at least one batch of oocytes before they were sampled (Murua et al. 2003). In our study, the results indicate a strong correlation between gonad weight and total fecundity, as the gonad weight explained $61 \%$ of the individual variability in fecundity. Hence, gonad weight appears to be an appropriate indicator for quantifying the reproductive condition of $T$. scabrus.

Small-medium hydrated oocytes with a large oil globule usually have pelagic development (Merrett and Haedrich 1997). In our study area, mature T. scabrus females were found to spawn their eggs in the winter season at their intermediate depth range (i.e., 900-1050). Based on our results, early recruits (i.e., 2 to $3 \mathrm{~cm} \mathrm{AL}$ ) first appear in spring, 3-4 months after the spawning period (winter), at their shallowest distribution depth (i.e., 400-600 m). Immature individuals (4-7 cm AL) were most abundant in autumn, and also at shallow depths nine months after the spawning 
period. This species was found to migrate ontogenetically to deeper depths, where reproduction takes place.

Analyzing population parameters in relation to reproduction is essential for understanding the biology of this species and developing effective fisheries management measures (Kjesbu and Kjesbu 2009). In this study, we characterized the population and reproductive biology of $T$. scabrus. Although this species is currently not of commercial value, an integrated management strategy for a potential future fishery should be developed within an ecosystem approach. 
Acknowledgements The authors would like to thank the Officers and crews of the R/V Garcia del Cid, F/V Montse III and Virgen del Vilar for helping to provide samples and the data necessary for our study. We also thank M Metaksakis and C Cerviño for helping with the histological analyses and JA Garcia for developing the study area map. This study was conducted within the RECS, PROMETEO and DOS MARES projects by the Spanish Science and Innovation Ministry CICYT (REN02/04556/C02/MAR; CTM2007-66316-C02/MAR; CTM2010-21810-C03-03/MAR, respectively, to JBC) and European Community's Seventh Framework Programme under the HERMIONE project (Grant Agreement 226354, to ERLL). UF-A is funded by a Spanish PhD doctoral fellowship FPI-2008. ERLL is funded by a Spanish JAE-CSIC postdoctoral grant. 


\section{References}

Aguzzi J, Company JB, Costa C, Menesatti P, Garcia JA, Bahamon N, Puig P, Sardà F (2010) Activity rhythms in the deep-sea crustacean: chronobiological challenges and potential technological scenarios. Front Biosci 16:131-150

Alekseyev FY, Alekseyeva YI, Zakharov AN (1992) Vitellogenesis, nature of spawning, fecundity and gonad maturity stages of the roundnose grenadier, Coryphaenoides rupestris, in the North Atlantic. J Ichthyol 33:32-45

Ashton WD (1972) The logit transformation with special reference to its uses in bioassay. Griffin's statistical monographs and courses, London

Bagenal TB (1973) Fish fecundity and its relations with the stock and recruitment. In: Gerking LSD (ed) Ecology of fresh water fish production. Third edition edn. FBA, Windermere, Ambleside, UK, pp 186-198

Bell JD, Lyle JM, Bulman CM, Graham KJ, Newton GM, Smith DC (1992) Spatial variation in reproduction, and occurrence of non-reproductive adults, in orange roughy, Hoplostethus atlanticus Collett (Trachichthyidae), from south-eastern Australia. J Fish Biol 40:107-122. doi:10.1111/j.1095-8649.1992.tb02558.x

Bergstad OA (1990) Distribution, population structure, growth and reproduction of the roundnose grenadier fish Coryphaenoides rupestris (Pisces: Macrouridae) in the deep waters of the Skagerrak. Mar Biol 107:25-39. doi:10.1007/bf01313239

Brown-Peterson NJ, Wyanski DM, Saborido-Rey F, Macewicz BJ, Lowerre-Barbieri SK (2011) A standardized terminology for describing reproductive development in fishes. Mar Coast Fish 3:52-70. doi:10.1080/19425120.2011.555724

Carrasson M, Matallanas J (2002) Diets of deep-sea macrourid fishes in the western Mediterranean. Mar Ecol Prog Ser 234:215-228

Childress $\mathrm{J}$ (1995) Are the physiological and biochemical adaptations of metabolism in deep-sea animals? . Trends Ecol Evol 10:30-36

Coggan RA, Gordon JDM, Merrett NR (1999) Aspects of the biology of Nezumia aequalis from the continental slope west of the British Isles. J Fish Biol 54:152170

Company JB, Sardà F (1998) Metabolic rates and energy content of deep-sea benthic decapod crustaceans in the western Mediterranean Sea. Deep-Sea Res 45:1861-1880

Company JB, Sardà F, Puig P, Cartes JE, Palanques A (2003) Duration and timing of reproduction in decapod crustaceans of the NW Mediterranean continental margin: Is there a general pattern?. Mar Ecol Prog Ser 261:201-216

D'Onghia G, Basanisi M, Matarrese A, Megli F (1999) Reproductive strategies in macrourid fish: seasonality or not?. Mar Ecol Prog Ser 184:189-196

D'Onghia G, Basanisi M, Tursi A (2000) Population structure, age and growth of macrourid fish from the upper slope of the Eastern-Central Mediterranean. J Fish Biol 56:1217-1238. doi:10.1111/j.1095-8649.2000.tb02135.x

D'Onghia G, Maiorano P, Sion L (2008) A review on the reproduction of grenadiers in the Mediterranean with new data on the gonad maturity and fecundity. Am Fish Soc Symp 63:169-184

D'Onghia G, Tursi A, Basanisi M (1996) Reproduction of macrourids in the upper slope of the north-western Ionian Sea. J Fish Biol 49:311-317. doi:10.1111/j.10958649.1996.tb06084.x

Drazen JC (2002) A seasonal analysis of the nutritional condition of deep-sea macrourid fishes in the north-east Pacific. J Fish Biol 60:1280-1295. doi:10.1111/j.1095-8649.2002.tb01720.x

Gage J, Tyler P (1991) Deep-sea biology: a natural history of organisms at the deepsea floor. Cambridge University Press, Cambridge 
Gordon JDM, Swan SC (1996) Validation of age readings from otoliths of juvenile roundnose grenadier, Coryphaenoides rupestris, a deep-water macrourid fish. J Fish Biol 49:289-297. doi:10.1111/j.1095-8649.1996.tb06082.x

Haedrich RL, Merrett NR (1988) Summary atlas of deep-living demersal fishes in the North Atlantic Basin. J Nat Hist 22:1325-1362

Herring P (2002) The biology of the deep ocean. Oxford University Press, Oxford

Hopkins TS (1985) Key Environments: Western Mediterranean In: Margalef R (ed) Physics of the sea. Pergamon Press, Oxford, pp 100-125

Hunter JR, Macewicz B (1985) Measurement of spawning frequency in multiple spawning fishes. In: Lasker R (ed) An egg production method for estimating spawning biomass of pelagic fish: application to the northern anchovy, Engraulis mordax. NOAA Tech Rep NMFS 36:79-93

Hunter J, Macewicz B, Lo N, Kimbrell C (1992) Fecundity, spawning, and maturity of female Dover sole Microstomus pacificus, with an evaluation of assumptions and precision. Fish Bull 90:101-123

Kelly CJ, Connolly PL, Bracken JJ (1996) Maturity, oocyte dynamics and fecundity of the roundnose grenadier from the Rockall Trough. J Fish Biol 49:5-17. doi:10.1111/j.1095-8649.1996.tb06064.x

Kennedy J, Witthames PR, Nash RD (2007) The concept of fecundity regulation in plaice (Pleuronectes platessa) tested on three Irish Sea spawning populations. Can J Fish Aquat Sci 64:587-601. doi:10.1139/f07-034

Kjesbu OS (2009) Applied fish reproductive biology: contribution of individual reproductive potential to recruitment and fisheries management. In: $\mathrm{T}$. Jakobsen MJF, B. A. Megrey, and E. Moksness (ed) Fish Reproductive Biology: implications for assessment and management. Wiley-Blackwell Scientific Publications, Oxford, UK, pp 293-332

Koslow JA, Boehlert GW, Gordon JDM, Haedrich RL, Lorance P, Parin N (2000) Continental slope and deep-sea fisheries: implications for a fragile ecosystem. ICES J Mar Sci 57:548-557. doi:10.1006/jmsc.2000.0722

Levin LA, Dayton PK (2009) Ecological theory and continental margins: where shallow meets deep. Trends Eco Evol 24:606-617

Lowerre-Barbieri SK, Ganias K, Saborido-Rey F, Murua H, Hunter JR (2011) Reproductive timing in marine fishes: variability, temporal scales, and methods. Mar Coast Fish 3:71-91. doi:10.1080/19425120.2011.556932

Macpherson E (1979) Ecological overlap between macrourids in the western Mediterranean. Sea Mar Biol 53:149-159

Macpherson E, Duarte CM (1991) Bathymetric trends in demersal fish size: is there a general relationship?. Mar Ecol Prog Ser 71:103-112

Margalef R (1986) Ecología. Omega, Barcelona

Marshall C, Browman H (2007) Disentangling the causes of maturation trends in exploited fish populations. Mar Ecol Prog Ser 335:249-251

Marshall NB (1965) Systematic and biological studies of the Macrourid fishes (Anacanthini-Teleostii). Deep-Sea Res 12:299-322

Massutí E, Morales-Nin B, Stefanescu C (1995) Distribution and biology of five grenadier fish (Pisces: Macrouridae) from the upper and middle slope of the northwestern Mediterranean. Deep-Sea Res 42:307-330

Merrett NR (1994) Reproduction in the North Atlantic oceanic ichthyofauna and the relationship between fecundity and species' sizes. Environ Biol Fishes 41:207245. doi:10.1007/bf00023814

Merrett NR, Haedrich J (1997) Deep-sea demersal fish and fisheries. Chapmann \& Hall, London

Morales-Nin B, Massutí E, Stefanescu C (1996) Distribution and biology of Alepocephalus rostratus from the Mediterranean Sea. J Fish Biol 48:1097-1112 
Moranta J, Massutí E, Palmer M, Gordon JDM (2007) Geographic and bathymetric trends in abundance, biomass and body size of four grenadier fishes along the Iberian coast in the western Mediterranean. Prog Oceanogr 72:63-83

Moranta J, Massutí E, Stefanescu C, Palmer M, Morales-Nin B (2008) Short-term temporal variability in fish community structure at two western Mediterranean slope locations. Deep-Sea Res 55:866-880

Motais R (1960) Quelques observations sur la biologie d'un Poisson abyssal, Trachyrhynchus trachyrhynchus Risso et sur les conditions de vie en mer profonde. Bull. Inst océanogr Monaco 1165:1-79

Murua H (2003) Population structure, growth and reproduction of roughhead grenadier on the Flemish Cap and Flemish Pass. J Fish Biol 63:356-373. doi:10.1046/j.1095-8649.2003.00158.x

Murua H, Kraus G, Saborido-Rey F, Witthames PR, Thorsen A, Junquera S (2003) Procedures to estimate fecundity of marine fish species in relation to their reproductive strategy. J Northwest Atl Fish Sci 33

Murua H, Motos L (2000) Reproductive biology of roughhead grenadier (Macrourus berglax Lacepède, 1801) (Pisces, Macrouridae), in Northwest Atlantic waters. Sarsia 85:393-402

Murua H, Saborido-Rey F (2003) Female reproductive strategies of marine fish species of the North Atlantic. J Northwest Atl Fish Sci 33:23-31

Polloni P, Haedrich R, Rowe G, Hovey Clifford C (1979) The size-depth relationship in deep ocean animals. Int Rev Gesamten Hydrobiol 64:39-46.

Porcu C, Follesa MC, Grazioli E, Deiana AM, Cau A (2010) Reproductive biology of a bathyal hermaphrodite fish, Bathypterois mediterraneus (Osteichthyes: Ipnopidae) from the south-eastern Sardinian Sea (Central-Western Mediterranean). J Mar Biol Assoc U K 90:719-728

Priede IG, Deary AR, Bailey DM, Smith KL (2003) Low activity and seasonal change in population size structure of grenadiers in the oligotrophic abyssal central North Pacific Ocean. J Fish Biol 63:187-196. doi:10.1046/j.1095-8649.2003.00142.x

Puig P, Company JB, Sardà F, Palanques A (2001) Responses of deep-water shrimp populations to intermediate nepheloid layer detachments on the Northwestern Mediterranean continental margin. Deep-Sea Res 48:2195-2207

Quintero-Hunter I, Grier H, Muscato M (1991) Enhancement of histological detail using metanil yellow as counterstain in periodic acid Schiff's hematoxylin staining of glycol methacrylate tissue sections. Biotech Histochem 66:169-172

Ramirez-Llodra E (2002) Fecundity and life-history strategies in marine invertebrates. Adv Mar Biol Volume 43:87-170

Roberts C (2002) Deep impact: the rising toll of fishing in the deep sea. Trends Eco Evol 17:242-245

Rotllant G, Moranta J, Massutí E, Sardà S, Morales-Nin B (2002) Reproductive biology of three gadiform fish species through the Mediterranean deep-sea range (147$1850 \mathrm{~m})$. Sci Mar 66:157-166

Sánchez P, Sartor P, Recasens L, Ligas A, Martin J, De Ranieri S, Demestre M (2007) Trawl catch composition during different fishing intensity periods in two Mediterranean demersal fishing grounds. Sci Mar 71:765-773

Sardà F, Calafat A, Flexas MM, Tselepides A, Canals M, Espino M, Tursi A (2004) An introduction to Mediterranean deep-sea biology. Sci Mar 68:7-38

Sardà F, Cartes JE (1993) Relationship between size and depth in decapod crustacean populations on the deep slope in the Western Mediterranean. Deep-Sea Res 40:2389-2400

Sardà F, Cartes JE, Company J, Albiol A (1998) A modified commercial trawl used to sample deep-sea megabenthos. Fish Sci 64:492-493

Sardà F, Company J, Rotllant G, Coll M (2009) Biological patterns and ecological indicators for Mediterranean fish and crustaceans below 1,000 m: a review. Rev Fish Biol Fish 19:329-347. doi:10.1007/s11160-009-9105-6 
Stefanescu C, Lloris D, Rucabado J (1993) Deep-sea fish assemblages in the Catalan Sea (western Mediterranean) below a depth of 1000 m. Deep-Sea Res 40:695707

Stefanescu C, Rucabado J, LLoris D (1992) Depht-size trends in the western Mediterranean demersal deep-sea fishes. Mar Ecol Prog Ser 81:205-213

Tecchio S, Ramírez-Llodra E, Sardà F, Company J (2011) Biodiversity of deep-sea demersal megafauna in western and central Mediterranean basins. Sci Mar 75:341-350

Thorsen A, Kjesbu OS (2001) A rapid method for stimation of oocyte size and potential fecundity in Atlantic cod using a computer- aided particle analysis system. J Sea Res 49:295-308

Treasure JW (1981) Some aspects of the reproductive biology of perch Perca fluviatilis L. Fecundity, maturation and spawning behaviour. J Fish Biol 18:729-740. doi:10.1111/j.1095-8649.1981.tb03814.x

Tyler CR, Sumpter JP (1996) Oocyte growth and development in teleosts. Rev Fish Biol Fish 6:287-318. doi:10.1007/bf00122584

Tyler PA, Grant A, Pain SL, Gage JD (1982) Is annual reproduction in deep-sea echinoderms a response to variability in their environment?. Nature $300: 747-$ 750

Wallace RA, Selman K (1981) Cellular and dynamic aspects of oocyte growth in Teleosts. Am Zool 21:325-343. doi:10.1093/icb/21.2.325

Zúñiga D, Flexas MM, Sanchez-Vidal A, Coenjaerts J, Calafat A, Jordà G, GarcíaOrellana J, Puigdefàbregas J, Canals $M$, Espino M, Sardà F, Company JB (2009) Particle fluxes dynamics in Blanes submarine canyon (Northwestern Mediterranean). Prog Oceanogr 82:239-251 


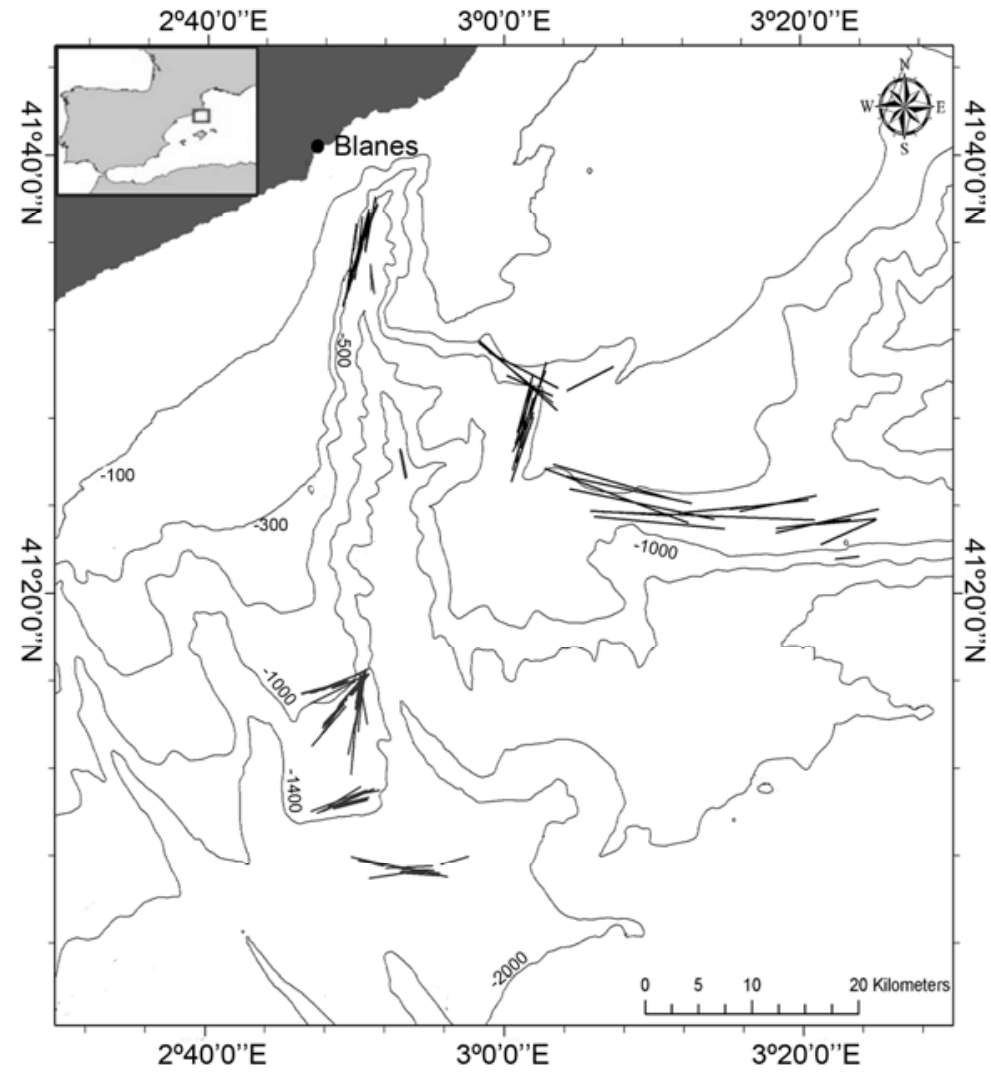

Fig. 1 Locations of the bottom trawl fishing stations in the RECS and PROMETEO projects (bathymetric data from Canals et al. 2004, using ESRI@ ArcMap ${ }^{\mathrm{TM}}$ 9.3). 


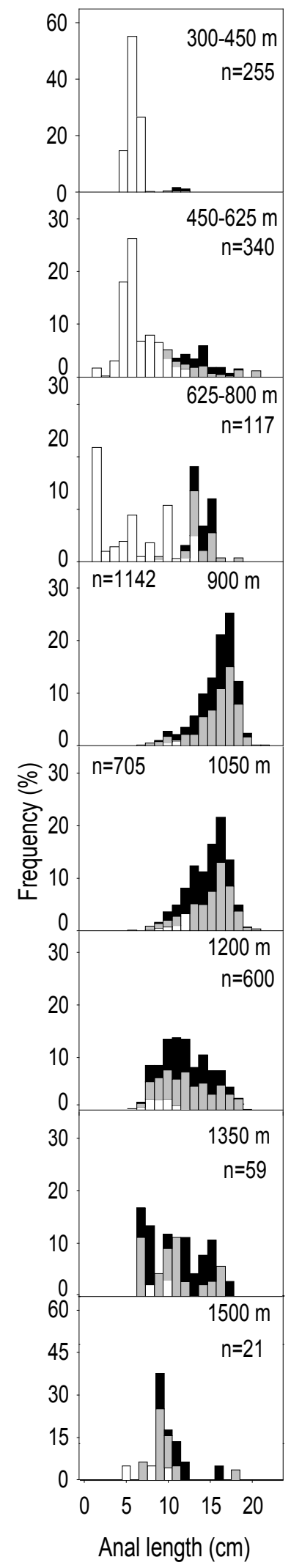

Fig. 2 Bathymetric length distribution of Trachyrincus scabrus by sex. White bars $=$ sex indeterminate; grey bars = females; blacks bars = males . 


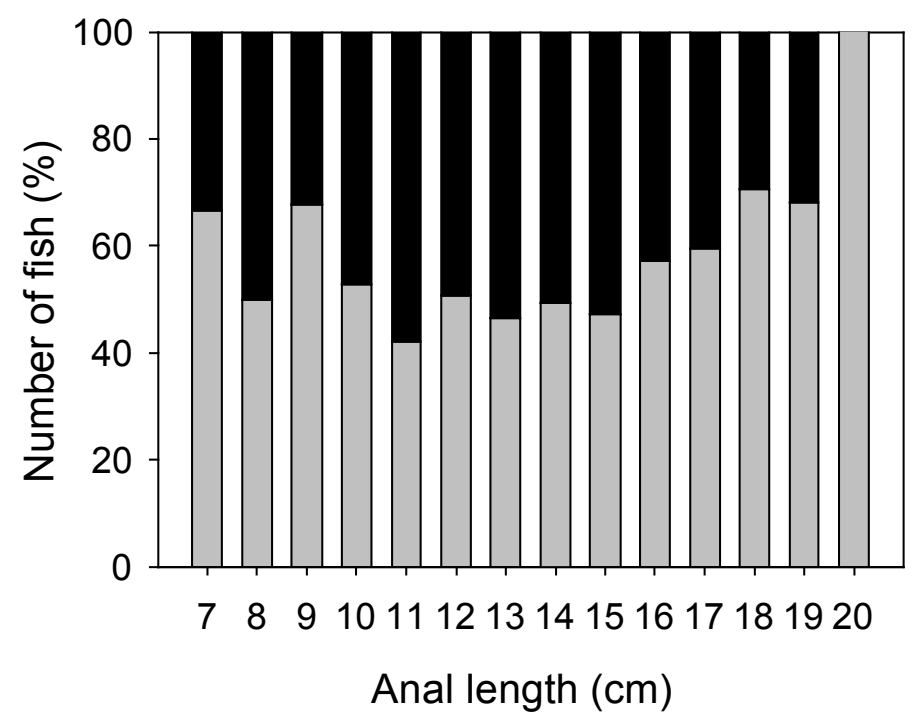

Fig. 3 Proportion of Trachyrincus scabrus males and females by size class (each class represented by $0.5 \mathrm{~cm}$ ). Grey bars = female; blacks bars = males.

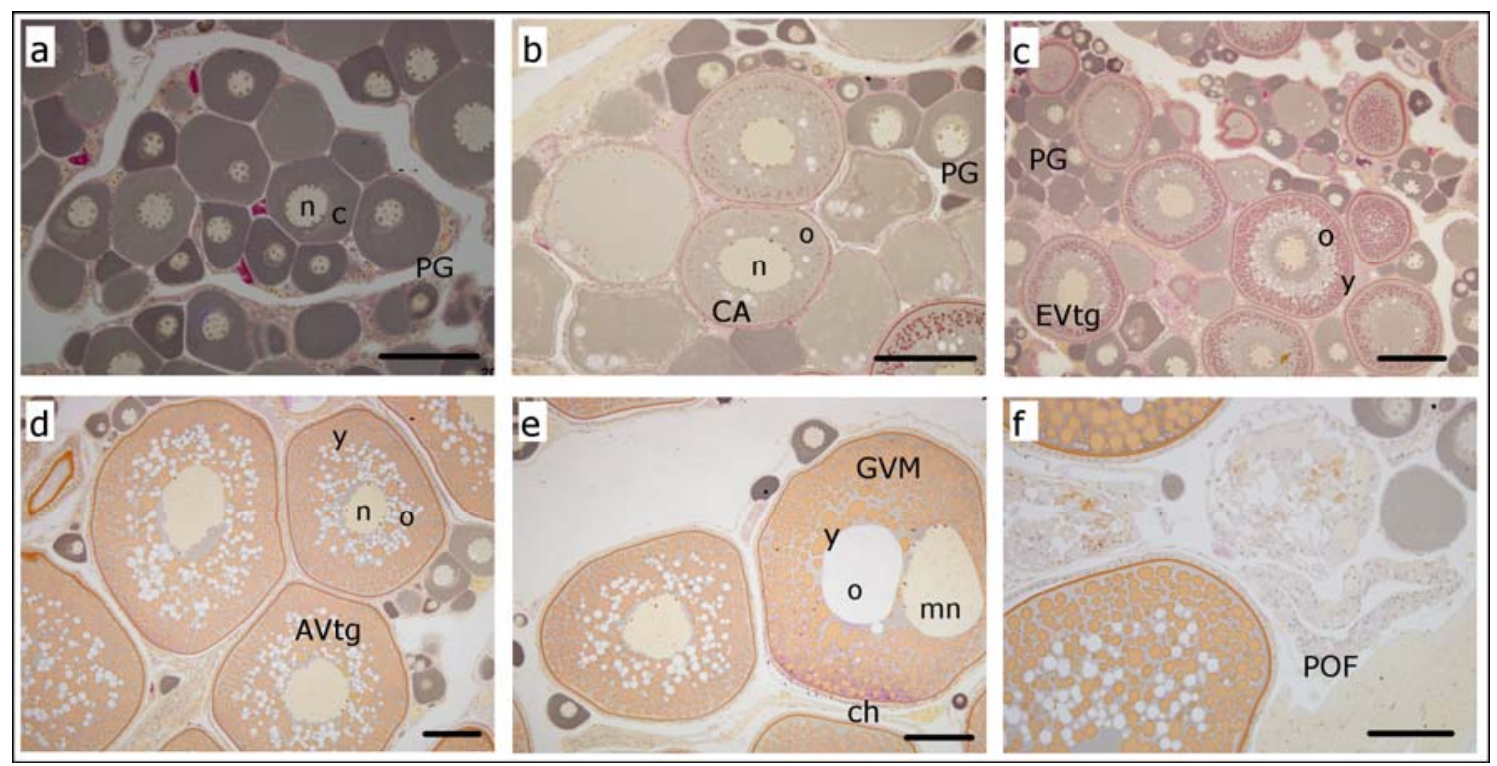

Fig. 4 Oocyte development in Trachyrincus scabrus: (a) primary growth stage (pg) oocyte; (b) cortical alveoli oocyte; (c) early vitellogenic oocyte; (d) advanced vitellogenic oocyte; (e) germinal vesicle migration oocyte; (f) postovulatory follicle (POF). c: cytoplasm; ca: cortical alveoli; ch: chorion; mn: migratory nucleus; n: nucleus; o: oil droplets; y: yolk vesicles. Scale $=0.50 \mu \mathrm{m}$. 


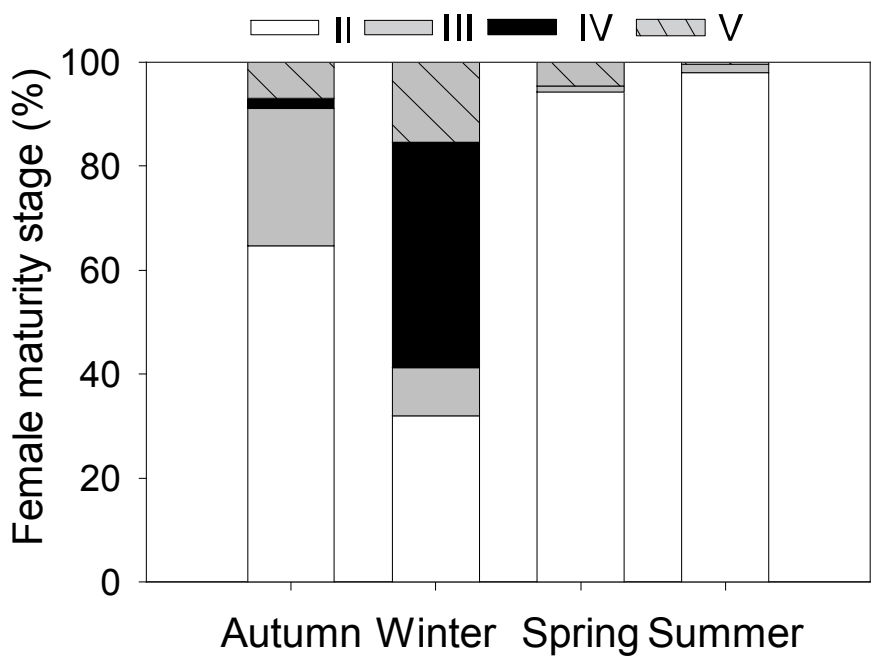

Fig. 5 Ovary maturity stages by season for Trachyrincus scabrus. II-VI: developingregenerating stage, III: spawning capable stage, IV: actively spawning stage, V: regressing stage.

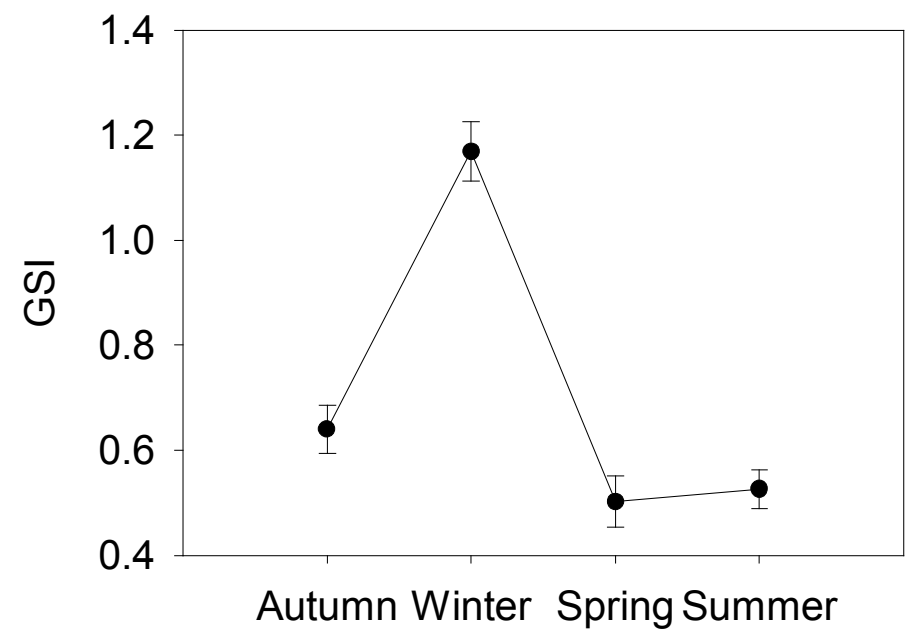

Fig. 6 Gonadosomatic index of Trachyrincus scabrus by season (mean \pm SD value). 


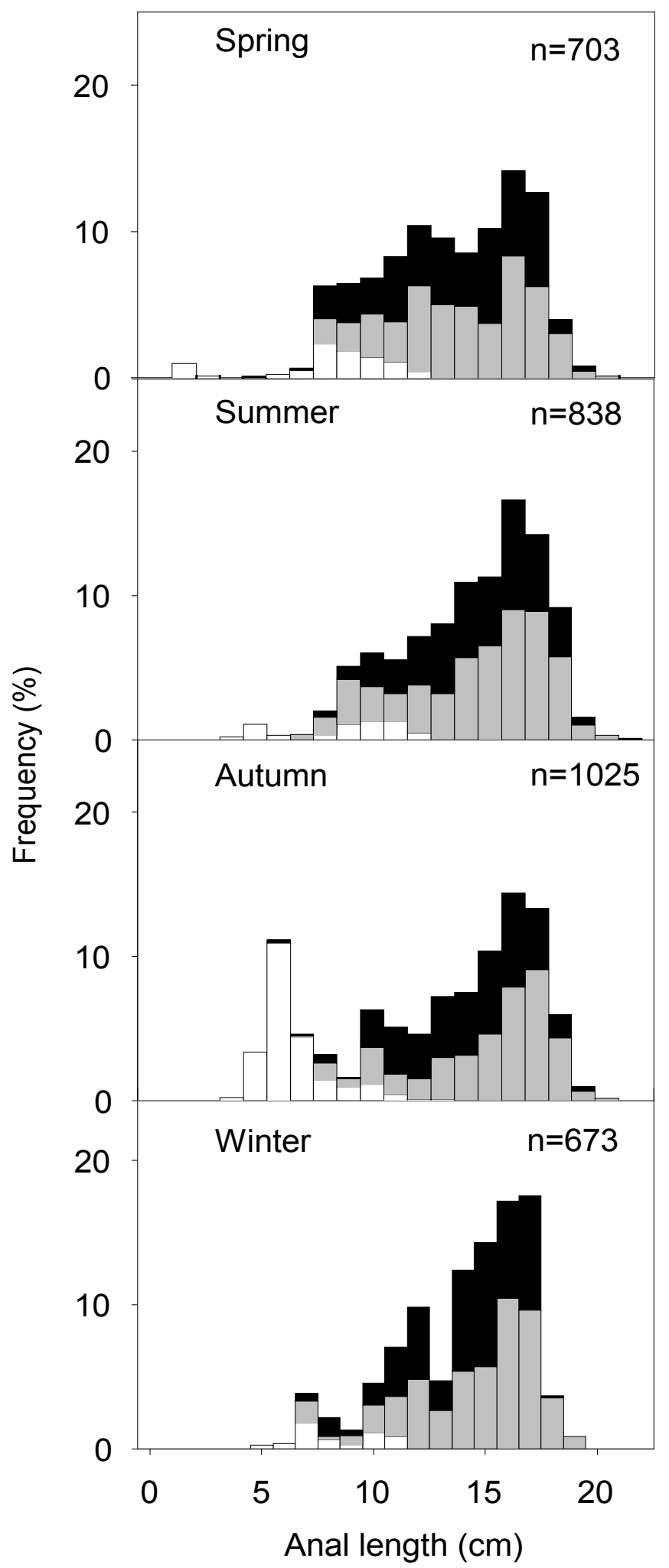

Fig. 7 Seasonal length-frequency distribution of Trachyrincus scabrus. White bars = sex indeterminate; grey bars = females; blacks bars = males . 


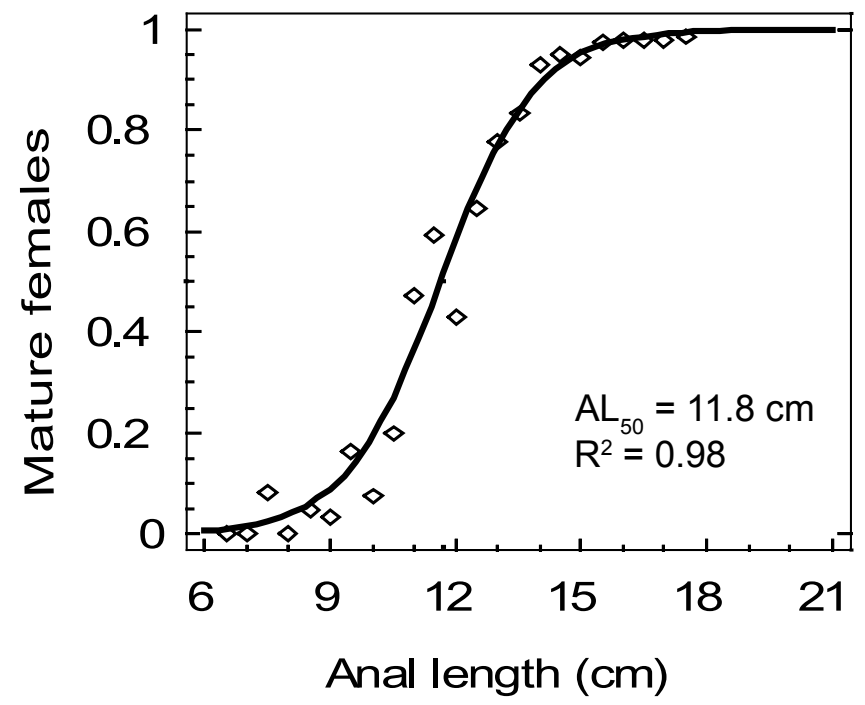

Fig. 8 Size at first maturity represented as a logistic curve of mature females (\%) as a function of size class. 


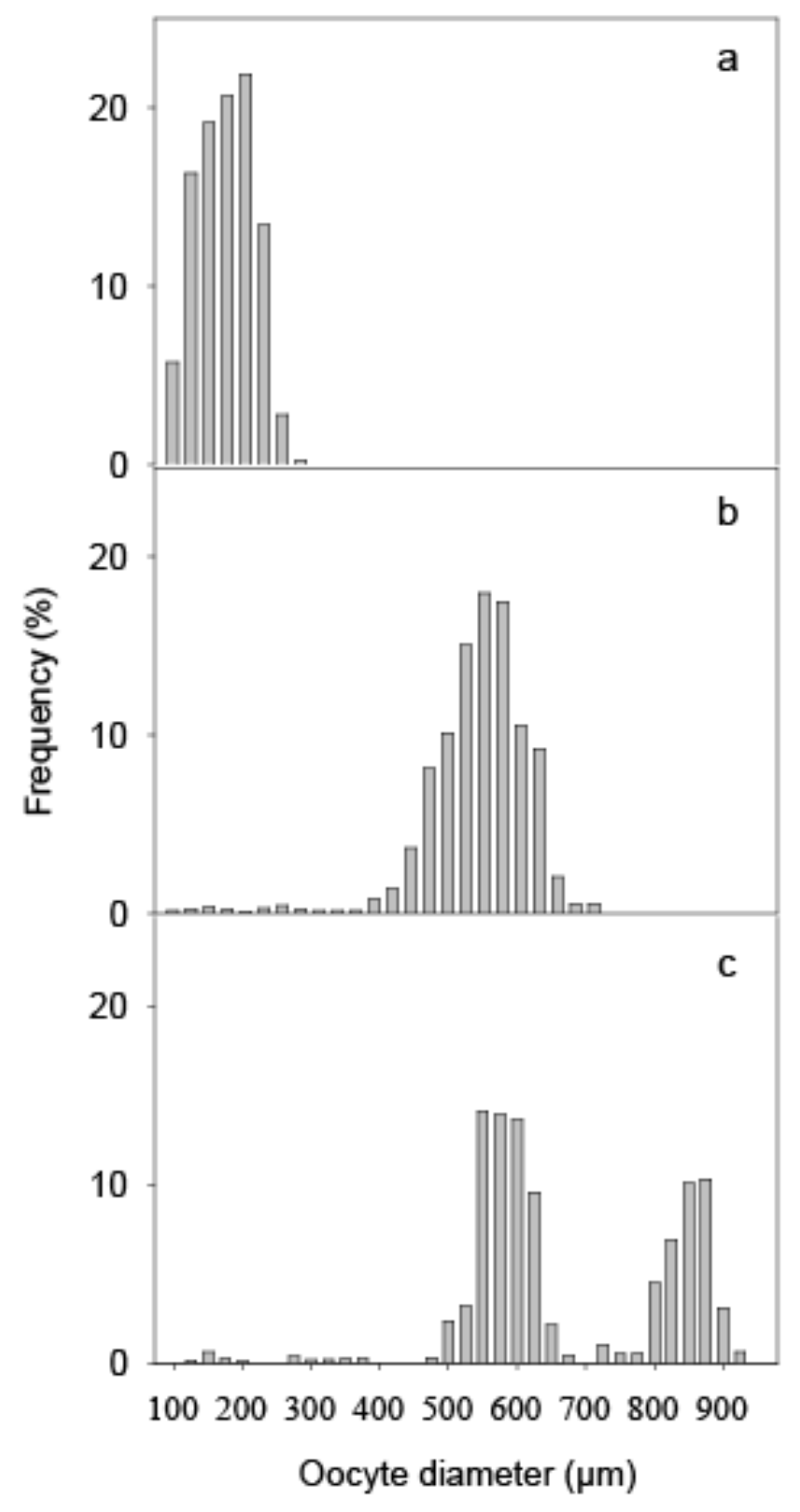

Fig. 9 Oocyte diameter distribution in (a) the developing stage, II, (b) the spawning capable stage, III, and (c) the spawning stage, IV. Each figure corresponds to an individual fish. 


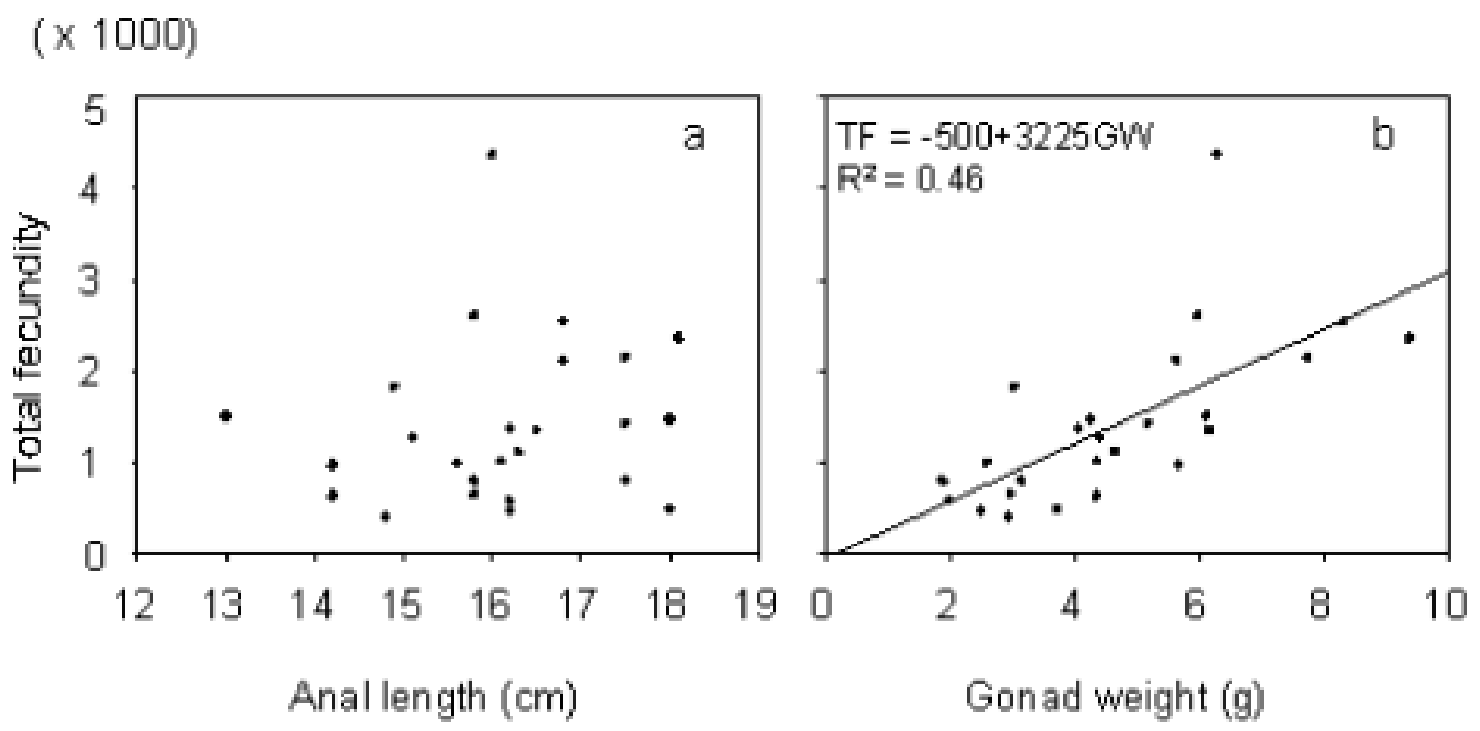

Fig. 10 Relationship between the total fecundity (number of advanced oocytes/female) and a) anal length (cm), and b) gonad weight ( $\mathrm{g})$. 
Table 1 Depth range, vessel, dates, number and sweet area of hauls and number of Trachyrincus scabrus specimens caught during the oceanographic cruises conducted within the RECS and PROMETEO scientific projects

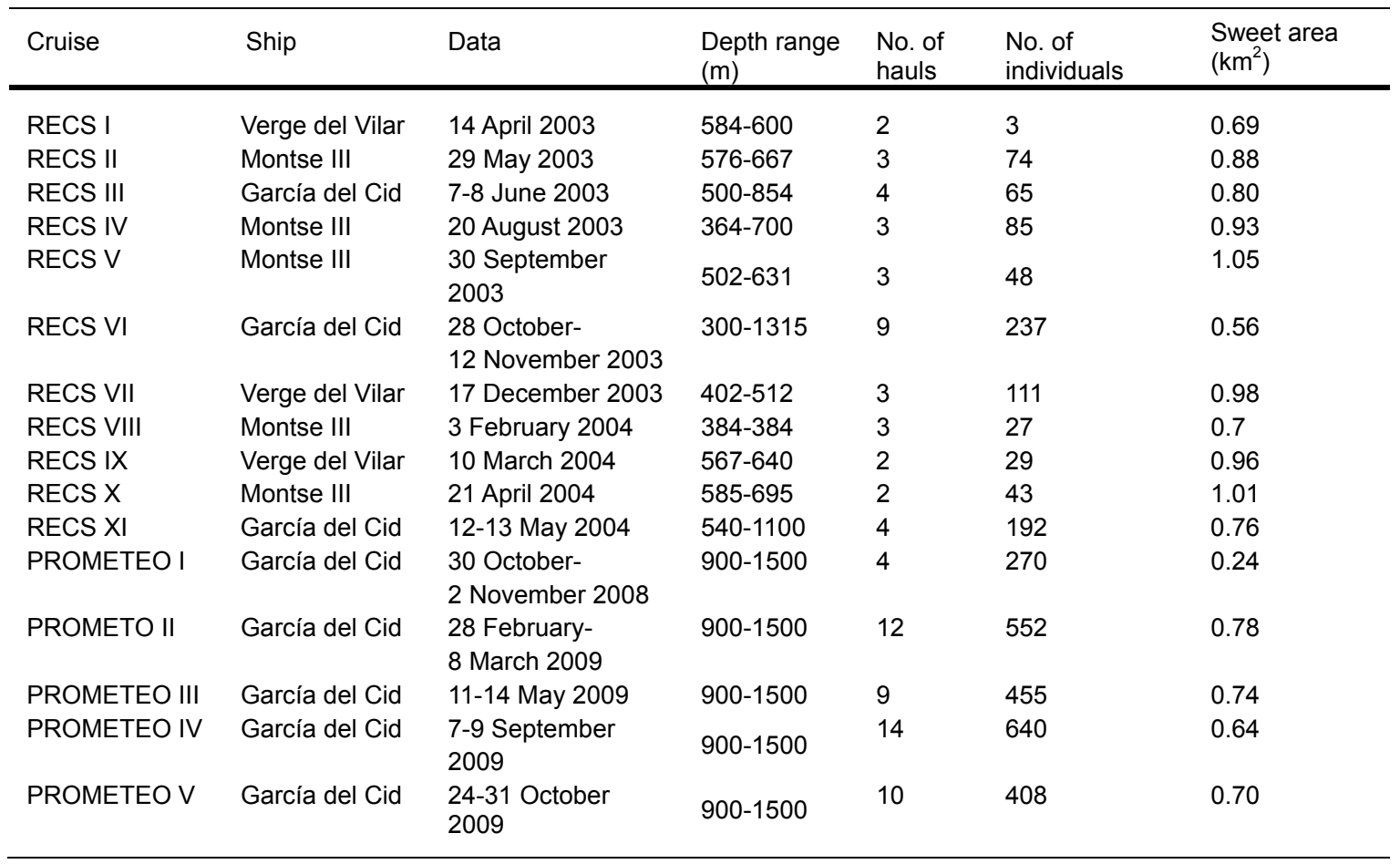

Table 2 Kolmogorov-Smirnov distance $(d)$ for the comparison of Trachyrincus scabrus size frequencies between depth ranges

\begin{tabular}{|c|c|c|c|c|c|c|c|}
\hline $450-625$ & $0.39^{*}$ & & & & & & \\
\hline 900 & $0.97^{*}$ & $0.72^{*}$ & $0.30^{*}$ & & & & \\
\hline 1050 & $0.97^{*}$ & $0.69^{*}$ & $0.30^{*}$ & 0.21 & & & \\
\hline 1500 & $0.87^{*}$ & $0.52^{*}$ & $0.55^{*}$ & $0.80^{*}$ & $0.73^{*}$ & $0.40^{*}$ & $0.31^{*}$ \\
\hline
\end{tabular}

* Significant values of $d .(p<0.05)$

Table 3 Percentage of females and males over total mature individuals captured of Trachyrincus scabrus by each sampling depth

\begin{tabular}{lllllllll}
\hline Depth (m) & $300-450$ & $450-625$ & $625-800$ & 900 & 1050 & 1200 & 1350 & 1500 \\
\hline $\begin{array}{l}\text { Female (\%) } \\
\text { Male (\%) }\end{array}$ & 25 & 51 & 55 & 57 & 57 & 51 & 47 \\
$\begin{array}{l}\text { No. of } \\
\text { individuals }\end{array}$ & 4 & 49 & 45 & 43 & 43 & 49 & 53 & 39 \\
\hline
\end{tabular}


Table 4 Macroscopic and microscopic descriptions of the developmental stages in the female Trachyrincus scabrus reproductive cycle

\begin{tabular}{|c|c|c|}
\hline Stage & Macroscopic features & Microscopic features \\
\hline I. Pre-growth & Ovaries small and translucent & Only present PG oocytes $(59-158 \mu \mathrm{m})(\mathrm{Fig} 4 \mathrm{a})$ \\
\hline II. Developing & $\begin{array}{l}\text { Larger and thicker ovaries, } \\
\text { whitish in color }\end{array}$ & $\begin{array}{l}\text { Presence of PG, CA (153-216 } \mu \mathrm{m}) \text { and } \mathrm{EVtg}(173- \\
285 \mu \mathrm{m} \text { ) characterized by early small proteinaceus } \\
\text { granules in the periphery and appearing after a } \\
\text { small oil droplets (o) (Fig } 4 \mathrm{~b}) \text { in the center of the } \\
\text { cytoplasm (Fig. 4c) }\end{array}$ \\
\hline $\begin{array}{l}\text { III. Spawning } \\
\text { capable }\end{array}$ & $\begin{array}{l}\text { Ovaries increase considerably in volume. } \\
\text { Oocyted visible to the naked eye }\end{array}$ & $\begin{array}{l}\text { Most of the ovary occupied with } \mathrm{AVtg}(275-571 \mu \mathrm{m}) \text {. } \\
\text { Big size proteinaceus granules distributed randomly } \\
\text { in the cytoplasm mixing around the oil droplets (Fig. } \\
\text { 4d). PG also present }\end{array}$ \\
\hline IV. Active spawning & Full ovary with hydrated oocytes visible & $\begin{array}{l}\text { Presence of PG, GVM }(519-747 \mu \mathrm{m}) \text { and hydrated } \\
\text { stage oocytes }(707-1040 \mu \mathrm{m})(\mathrm{Fig} 4 \mathrm{e})\end{array}$ \\
\hline V. Regressing & $\begin{array}{l}\text { Ovary flaccid and reddish. Predominant } \\
\text { blood vessels and empty space }\end{array}$ & $\begin{array}{l}\text { Characterized by presence of PG oocyte, recent } \\
\text { POF and widespread atresia (Fig 4f) }\end{array}$ \\
\hline VI. Regenerating & Ovary closer and pinkish & $\begin{array}{l}\text { Oogonia and PG. Few atresia and old POF } \\
\text { presented }\end{array}$ \\
\hline
\end{tabular}

$\mathrm{AVtg}=$ advance vitellogenic oocyte; $\mathrm{CA}=$ cortical alveolar; $\mathrm{EVtg}=$ early vitellogenic oocyte; $\mathrm{GVM}=$ germinal vesicle migration; $P G=$ primary growth oocyte; $P O F=$ postovulatory follicle

Table 5 Percentage of maturity stages in relation to depth of capture Trachyrincus scabrus during winter (i.e., the season in which there are most mature females)

\begin{tabular}{lllllllll}
\hline & \multicolumn{7}{c}{ Depth intervals (m) } \\
\cline { 2 - 8 } Maturity stage (\%) & $300-450$ & $450-625$ & $625-800$ & 900 & 1050 & 1200 & 1350 & 1500 \\
\hline Stage II & 0 & 2 & 6 & 70 & 11 & 11 & 0 & 0 \\
Stage III & 0 & 0 & 11 & $\mathbf{4 4}$ & 22 & 11 & 0 & 11 \\
Stage IV & 0 & 0 & 0 & 34 & $\mathbf{4 6}$ & 15 & 5 & 0 \\
Stage V & 0 & 0 & 0 & $\mathbf{6 8}$ & 24 & 8 & 0 & 0 \\
No. of individuals & 0 & 1 & 4 & $\mathbf{7 3}$ & 33 & 15 & 2 & 1 \\
\hline
\end{tabular}

In bold; the highest percentage of each reproductive stage at different depths

Table 6 Fecundity data for Trachyrincus scabrus species

\begin{tabular}{llll}
\hline Parameters & No. of individuals & Range & X \pm SD \\
\hline Total fecundity & 25 & $4189-43644$ & $14191 \pm 8998$ \\
Relative total fecundity & 25 & $2413-23628$ & $82 \pm 52$ \\
Batch fecundity & 12 & $2582-9489$ & $5571 \pm 2098$ \\
Relative batch fecundity & 12 & $18-76$ & $33 \pm 16$ \\
\hline
\end{tabular}

Total fecundity (number of advance oocytes/female), batch fecundity (hydrated oocyte/female), relative total fecundity (number of advance oocytes/gr of female gonad free), relative batch fecundity (number of hydrated oocytes/gr of female gonad free) 